\title{
Modifikasi Media MS Dengan Penambahan Air Kelapa Untuk Subkultur I Anggrek Cymbidium
}

\author{
Joe Pratama, Nilahayati
}

Email : Joeapra@gmail.com

\begin{abstract}
ABSTRAK
Anggrek Cyimbidium adalah jenis anggrek yang sangat popular di Indonesia dengan ciri khas bunganya yang menyerupai perahu. Optimalisasi budidaya anggrek dengan teknik kultur jaringan dapat dilakukan dengan metode modifikasi media MS. Penggunaan jenis zat pengatur tumbuh alami dengan konsentrasi yang tepat merupakan salah satu kunci keberhasilan dalam kultur jaringan serta dapat menekan biaya untuk kultur jaringan anggrek. Penelitian ini bertujuan untuk mengetahui pengaruh modifikasi media MS dengan penambahan air kelapa terhadap subkultur anggrek Cymbidium secara in vitro. Penelitian Menggunakan Rancangan acak lengkap faktorial dengan 6 ulangan yaitu modifikasi media MS; media MS penuh (M1), media 1/2 MS (M2), dan media 1/4 MS (M3) dan konsentrasi air kelapa, yaitu $0 \mathrm{ml}$ air kelapa (K1), $100 \mathrm{ml}$ air kelapa (K2), $200 \mathrm{ml}$ air kelapa (K3), dan $300 \mathrm{ml}$ air kelapa (K4). Variable pengamatan meliputi waktu persentase tumbuh tunas, jumlah tunas, jumlah akar, dan tinggi tunas. Hasil penelitian menunjukkan bahwa terjadi interaksi antara perlakuan modifikasi media MS dengan penambahan air kelapa untuk subkutur I anggrek Cymbidium terhadap peubah persentase tumbuh tunas di 2-8 MST, jumlah tunas di 4, 6, dan 8 MST, jumlah akar di 2-8 MST, dan tinggi tunas di 8 MST. Namun tidak berbeda nyata terhadap peubah jumlah tunas di 2 MST.
\end{abstract}

Kata kunci : modifikasi MS, anggrek Cymbidium, in vitro, air kelapa.

\begin{abstract}
Cyimbidium orchids are a type of orchid that is very popular in Indonesia with the characteristic flower that resembles a boat. Optimization of orchid cultivation with tissue culture techniques can be carried out using MS media modification method. Using natural growth regulators with the right concentration is one of the keys to success in tissue culture and can reduce costs for orchid tissue culture. This study aims to determine the effect of MS media modification by adding coconut water to the Cymbidium orchid subculture in vitro. Research using factorial complete randomized design with 6 replications. The first factor is the modification level of MS media, namely: full MS medium (M1), medium $1 / 2$ MS (M2), and media $1 / 4$ MS (M3). The second factor is the level of concentration of coconut water, which is namely as $0 \mathrm{ml}$ of coconut water (K1), $100 \mathrm{ml}$ of coconut water (K2),

$200 \mathrm{ml}$ of coconut water (K3), and $300 \mathrm{ml}$ of coconut water (K4). Observation variables include time of shoot growth, number of shoots, number of roots, and shoot height. The results showed that there was an interaction between MS media modification treatment with the addition of coconut water for subculture I of Cymbidium orchid to the percentage of shoot growth at 2-8 MST, the number of shoots at 4, 6, and $8 \mathrm{MST}$, the number of roots in 2-8 MST, and shoot height at $8 \mathrm{MST}$. However, it was not significantly different from the number of shoots at $2 \mathrm{MST}$.
\end{abstract}

Keywords: MS modification, Cymbidium orchids, in vitro, coconut water.

${ }^{1}$ Program StudiAgroekoteknologi, FakultasPertanian, UniversitasMalikussaleh 


\section{Pendahuluan}

Tanaman anggrek (Orchidaceae) termasuk tanaman hias yang mempuyai nilai keindahan (artistik) pada bunganya. Tanaman anggrek memiliki nilai ekonomis yang tinggi karena bentuknya unik dan warnanya menarik, sehingga membuat tanaman ini disebut "Queen of flower". Daya tahannya lebih lama dari pada bunga potong komersial lainnya seperti mawar, anyelir, dan gladiol (Widiastoety et al., 2010).

Budidaya tanaman anggrek dapat dilakukan dengan dua cara, yaitu dengan cara konvensional dan kultur jaringan. Kultur jaringan tanaman merupakan teknik menumbuh kembangkan bagian tanaman, baik berupa sel, jaringan, atau organ dalam kondisi aseptik secara in vitro. Penyediaan bibit yang bermutu, massal dan seragam maka perbanyakan anggrek, mutlak dilakukan melalui kultur jaringan (Yusnita, 2003).

Keberhasilan kultur jaringan tanaman dalam perbanyakan tanaman tergantung pada media yang digunakan. Media Murashige and Skoog (MS) dicirikan dengan kandungan garamgaram anorganik yang tinggi. Media MS merupakan media yang sangat luas pemakaiannya karena mengandung unsur hara makro dan mikro yang lengkap sehingga dapat digunakan untuk berbagai spesies tanaman (Mardin, 2002). Media MS sering digunakan karena cukup memenuhi unsur hara makro, mikro dan vitamin untuk pertumbuhan tanaman (Marlina, 2004). Wetherell (1982) menyatakan bahwa untuk tujuan tertentu komposisi media dapat dimodifikasi lebih lanjut.

Air kelapa merupakan senyawa organik yang mengandung 1,3 diphenilurea, zeatin, zeatin gluoksida, zeatin ribosida, kadar $\mathrm{K}$ dan $\mathrm{Cl}$ tinggi, sukrosa, fruktosa, glukosa, protein, karbohidrat, mineral, vitamin, sedikit lemak, Ca dan P (Yunita, 2011). Zeatin, zeatin gluoksida, zeatin ribosida merupakan ZPT yang dapat meningkatkan pembelahan sel dan perpanjangan sel. Asam amino, gula dan vitamin dapat meningkatkan metabolisme sel dan berperan sebagai energi, enzim dan co-faktor.

Perlakuan air kelapa secara tunggal pada konsentrasi $250 \quad \mathrm{ml} / 1$ mampu menghasilkan pembentukan daun dan akar lebih cepat pada kultur in vitro anggrek (Phalaenopsis amabilis BL.) (Bey et al., 2006).

Tujuan akhir dari penelitian ini adalah untuk melihat pengaruh dari modifikasi media MS dan beberapa komposisi penambahan air kelapa terhadap pertumbuhan tanaman anggrek Cymbidium secara in vitro.

\section{Bahan Dan Metode}

\section{Tempat dan Waktu Penelitian.}

Penelitian dilaksanakan di Laboratorium Kultur Jaringan Fakultas Pertanian Universitas Malikussaleh, AcehUtara. Penelitian ini berlangsung pada bulan Maret- Mei 2018.

\section{Alat dan Bahan Penelitian.}

Alat yang digunakan dalam
penelitian ini adalah timbangan analitik, pipet ukur, gelas ukur, labu takar, beaker glass, erlenmeyer, $\mathrm{pH}$ meter, autoclave, oven, panci, hot plate, spatula, magnetic stirrer, kompor dan tabung gas, botol kultur, rak kultur, pengaduk, kulkas, Laminar Air Flow (LAF), pisau scalpel, petri dish, bunsen, kertas buram, kertas label, tissue, karet gelang, hand sprayer, plastic wrap $0,03 \mathrm{~mm}$, pinset, gunting, kamera dan alat tulis.

Bahan yang digunakan dalam pelaksanaan penelitian ini adalah planlet dari tanaman anggrek yang berumur 12 bulan, media dasar Murashige dan Skoog (MS), air kelapa, aquadest, gula pasir, alkohol 70\% dan 96\%, aquadest steril, 
deterjen, dan agar-agar.

\section{Metode Penelitian.}

Metode yang digunakan dalam penelitian ini menggunakan rancangan lingkungan berupa Rancangan Acak Lengkap (RAL) faktorial. Faktor pertama adalah modifikasi media MS, terdiri dari 3 taraf M1 (MS penuh), M2 ( $1 / 2 \mathrm{MS})$ dan M3 ( $1 / 4$ MS $)$. Faktor kedua adalah penambahan konsentrasi air kelapa, terdiri dari 4 taraf $\mathrm{K} 1 \quad(0 \mathrm{ml}), \mathrm{K} 2$ (100 $\mathrm{ml})$, K3 $(200 \mathrm{ml})$, K4 (300 ml). Oleh karena itu diperoleh 12 kombinasi perlakuan dan masing-masing diulang sebanyak 6 kali, sehingga diperoleh 72 satuan percobaan.

\section{Pembuatan media.}

Pembuatan media ms ditambahkan air kelapa dengan konsentrasi yang berbeda-beda, yakni 0 $\mathrm{ml} / \mathrm{l}$ (tanpa air kelapa), $100 \mathrm{ml} / 1,200$ $\mathrm{ml} / 1, \quad 300 \mathrm{ml} / 1$. Media dibagi menjadi 3 taraf, untuk pembuatan media masingmasing larutan stok dipipet berdasarkan volume yang diperlukan untuk media MS penuh dan modifikasi (MS $1 / 2$ dan MS 1/4). Larutan stok kemudian dituangkan kedalam gelas ukur, dan ditambah air kelapa sesuai perlakuan dan ditera dengan air steril sampai 1 liter, selanjutnya larutan dituangkan ke dalam wadah panci lalu ditambahkan gula sebanyak $30 \mathrm{~g} / \mathrm{L}$ dan diaduk sampai larut. Larutan dikondisikan pada $\mathrm{pH}$ 5,7-5,8 dengan menambahkan $\mathrm{NaOH}$ untuk menaikkan $\mathrm{pH}$ dan $\mathrm{HCL}$ untuk menurunkan $\mathrm{pH}$. Larutan ditambahkan agar agar 6,5 g/l, diaduk dan dimasak di atas

kompor sampai mendidih. Larutan media dimasukkan ke dalam botol kultur kira-kira $20 \mathrm{ml} /$ botol. Botol

kultur ditutup rapat dengan penutup plastik. Botol yang sudah berisi media disterilisasi dalam autoclave selama 12 menit dengan suhu $121^{\circ} \mathrm{C}$. Botol yang sudah steril diletakkan pada rak kultur di ruang inkubasi, dengan suhu ruang diatur $24-26^{\circ} \mathrm{C}$.

\section{Hasil Dan Pembahasan}

\section{Hasil}

Pertumbuhan subkultur tanaman anggrek menunjukkan hasil yang baik sejak awal penanaman sampai 8 minggu setelah tanam (MST). Terjadi interaksi terhadap perlakuan modifikasi media MS dan penambahan air kelapa pada semua peubah yang diamati. Selama penelitian tidak ada eksplan yang terkontaminasi pada tiap botol. Rekapitulasi hasil analisis ragam terhadap beberapa peubah yang diamati akibat modifikasi media MS dan penambahan air kelapa untuk subkultur I tanaman anggrek Cymbidium disajikan pada Tabel 1.

Tabel 1. Rekapitulasi hasil analisis ragam pada peubah persentase tumbuh tunas, jumlah tunas, jumlah akar dan tingggi tunas tanaman subkultur I anggrek Cymbidium.

\begin{tabular}{|c|c|c|c|c|}
\hline \multirow{2}{*}{ Peubah } & \multicolumn{4}{|c|}{ Faktor } \\
\hline & $\mathbf{M}$ & $\mathbf{K}$ & $\underset{\mathbf{K}}{\mathbf{M} \mathbf{x}}$ & KK $(\%)$ \\
\hline \multicolumn{5}{|l|}{$\begin{array}{l}\text { Persentase Tumbuh } \\
\text { Tunas }\end{array}$} \\
\hline $2 \mathrm{MST}$ & $* *$ & $* *$ & $*$ & 8,53 \\
\hline $4 \mathrm{MST}$ & $* *$ & $* *$ & $* *$ & 5,68 \\
\hline $6 \mathrm{MST}$ & $* *$ & $* *$ & $* *$ & 5,04 \\
\hline $8 \mathrm{MST}$ & $* *$ & $* *$ & $* *$ & 3,32 \\
\hline \multicolumn{5}{|l|}{ Jumlah Tunas } \\
\hline $2 \mathrm{MST}$ & $*$ & $* *$ & tn & 1,72 \\
\hline $4 \mathrm{MST}$ & $*$ & $* *$ & $* *$ & 1,58 \\
\hline $6 \mathrm{MST}$ & $*$ & $* *$ & $* *$ & 2,58 \\
\hline $8 \mathrm{MST}$ & $* *$ & $* *$ & $* *$ & 3,54 \\
\hline \multicolumn{5}{|l|}{ Jumlah Akar } \\
\hline $2 \mathrm{MST}$ & $*$ & * & $* *$ & 1,54 \\
\hline $4 \mathrm{MST}$ & $\operatorname{tn}$ & $* *$ & $* *$ & 0,86 \\
\hline $6 \mathrm{MST}$ & $\operatorname{tn}$ & $* *$ & $* *$ & 0,97 \\
\hline $8 \mathrm{MST}$ & $* *$ & $* *$ & $* *$ & 1,29 \\
\hline \multicolumn{5}{|l|}{ Tinggi Tanaman } \\
\hline $8 \mathrm{MST}$ & $* *$ & $* *$ & $* *$ & 1,79 \\
\hline
\end{tabular}

Ket : $*=$ berbeda nyata, $* *=$ berbeda sangat nyata, $\mathrm{tn}=$ tidak berbeda nyata, $\mathrm{KK}=$ Koefisien Keragaman, $\mathrm{M}=$ Media MS, $\mathrm{K}=$ Konsentrasi air kelapa 


\section{Persentase Tumbuh Tunas.}

Hasil analisis ragam terhadap persentase tumbuh tunas menunjukkan adanya pengaruh sangat nyata akibat modifikasi media MS pada umur 2, 4, 6 dan 8 MST. Pada pemberian air kelapa juga menunjukkan adanya pengaruh sangat nyata terhadap persentase tumbuh tunas pada umur 2, 4, 6 dan 8 MST. Terdapat interaksi yang sangata nyata antara modifikasi media MS dan pemberian air kelapa pada umur 2, 4, 6 dan 8 MST (Tabel 2). Data hasil uji lanjut pada peubah persentase tumbuh tunas dengan

menggunakan DMRT taraf 5\%disajikan pada Tabel 2.

Tabel 2.Persentase tumbuh tunas akibat I nteraksi antara perlakuan modifikasi media MS dan penambahan air kelapa terhadap sub kultur I tanaman anggrek Cymbidium.

\begin{tabular}{|c|c|c|c|c|}
\hline \multirow[b]{2}{*}{ Perlakuan } & \multicolumn{4}{|c|}{ Persentase Tumbuh Tunas (\%) } \\
\hline & 2 MST & 4 MST & $6 \mathrm{MST}$ & $\begin{array}{c}8 \\
\text { MST }\end{array}$ \\
\hline M1K1 & $\begin{array}{c}25.00 \\
(1.11) \mathrm{bcd}\end{array}$ & $\begin{array}{c}79.17 \\
(1.32) \\
a b\end{array}$ & $\begin{array}{c}83.33 \\
(1.34) \\
a b\end{array}$ & $\begin{array}{l}95.83 \\
(1.39) \mathrm{a}\end{array}$ \\
\hline M1K2 & $\begin{array}{c}20.83 \\
(1.09) \mathrm{cd}\end{array}$ & $\begin{array}{c}62.50 \\
(1.27) b\end{array}$ & $\begin{array}{c}75.00 \\
(1.32) \mathrm{b}\end{array}$ & $\begin{array}{l}75.00 \\
(1.32) \mathrm{b}\end{array}$ \\
\hline M1K3 & $\begin{array}{c}0.00(1.00) \\
\mathrm{d}\end{array}$ & $\begin{array}{c}0.00 \\
(1.00) \mathrm{d}\end{array}$ & $\begin{array}{c}0.00 \\
(1.00) \mathrm{d}\end{array}$ & $\begin{array}{l}0.00 \\
(1.00) \mathrm{e}\end{array}$ \\
\hline M1K4 & $\begin{array}{c}8.03(1.03) \\
\mathrm{d}\end{array}$ & & & \\
\hline M2K1 & $\begin{array}{c}45.83(1.20) \\
\text { abc }\end{array}$ & $\begin{array}{c}100.00 \\
(1.41) \mathrm{a}\end{array}$ & $\begin{array}{c}100.00 \\
(1.41) \mathrm{a}\end{array}$ & $\begin{array}{l}100.00 \\
(1.4) 1 \mathrm{a}\end{array}$ \\
\hline M2K2 & $\begin{array}{c}66.67(1.28) \\
\mathrm{a} \\
\end{array}$ & $\begin{array}{c}100.00 \\
(1.41) \mathrm{a}\end{array}$ & $\begin{array}{c}100.00 \\
(1.41) \mathrm{a}\end{array}$ & $\begin{array}{l}100.00 \\
(1.41) \mathrm{a}\end{array}$ \\
\hline M2K3 & $\begin{array}{c}0.00 \\
(1.00) \mathrm{d}\end{array}$ & $\begin{array}{c}4.17 \\
(1.01) \mathrm{d}\end{array}$ & $\begin{array}{c}12.50 \\
(1.05) \mathrm{d}\end{array}$ & $\begin{array}{l}20.83 \\
(1.09) \mathrm{d}\end{array}$ \\
\hline $\mathrm{M} 2 \mathrm{~K} 4$ & $\begin{array}{c}50.00(1.22) \\
\mathrm{ab}\end{array}$ & $\begin{array}{c}100.00 \\
(1.41) \mathrm{a} \\
\end{array}$ & $\begin{array}{c}100.00 \\
(1.41) \mathrm{a} \\
\end{array}$ & $\begin{array}{l}100.00 \\
(1.41) \mathrm{a} \\
\end{array}$ \\
\hline M3K1 & $\begin{array}{c}54.17(1.23) \\
\mathrm{ab}\end{array}$ & $\begin{array}{c}100.00 \\
(1.41) \mathrm{a}\end{array}$ & $\begin{array}{c}100.00 \\
(1.41) \mathrm{a} \\
\end{array}$ & $\begin{array}{l}100.00 \\
(1.41) \mathrm{a} \\
\end{array}$ \\
\hline M3K2 & $\begin{array}{c}25.00(1.11) \\
\text { bcd }\end{array}$ & $\begin{array}{c}83.33 \\
(1.35) \mathrm{ab} \\
\end{array}$ & $\begin{array}{c}100.00 \\
(1.41) \mathrm{a} \\
\end{array}$ & $\begin{array}{l}100.00 \\
(1.41) \mathrm{a} \\
\end{array}$ \\
\hline M3K3 & $\begin{array}{c}0.00(1.00) \\
\mathrm{d}\end{array}$ & $\begin{array}{c}33.33 \\
(1.15) \mathrm{c}\end{array}$ & $\begin{array}{c}41.66 \\
(1.18) \mathrm{c}\end{array}$ & $\begin{array}{l}41.66 \\
(1.18) \mathrm{c}\end{array}$ \\
\hline M3K4 & $\begin{array}{c}12.50(1.05) \\
\mathrm{d}\end{array}$ & $\begin{array}{c}33.33 \\
(1.15) \mathrm{c} \\
\end{array}$ & $\begin{array}{c}70.83 \\
(1.30) b \\
\end{array}$ & $\begin{array}{l}70.83 \\
(1.30) \mathrm{b} \\
\end{array}$ \\
\hline
\end{tabular}

Ket : Angka yang diikuti oleh huruf yang sama pada kolom yang sama tidak berbeda nyata berdasarkan uji DMRT pada 0,05. Angka dalam kurung adalah data hasil transformasi $=\mathrm{x}(\mathrm{x} 0,01)$ dan $=\mathrm{SQRT}(\mathrm{x}+1)$
Tabel 2 menunjukkan bahwa persentase tumbuh tunas tertinggi terletak pada kombinasi perlakuan M2K2 (media 1/2 $\mathrm{MS}+100 \mathrm{ml}$ air kelapa) yaitu sebesar $100 \%$ pada umur 8 MST. Sedangkan persentase tumbuh tunas terendah terletak pada kombinasi perlakuan M1K3 (media MS penuh + $200 \mathrm{ml}$ air kelapa) yaitu sebesar $0.00 \%$ pada umur $8 \mathrm{MST}$.

\subsubsection{Jumlah Tunas.}

Hasil analisis ragam terhadap jumlah menunjukkan adanya pengaruh sangat nyata akibat modifikasi media MS pada umur 2, 4, 6 dan 8 MST. Pada pemberian air kelapa juga menunjukkan adanya pengaruh sangat nyata terhadap jumlah tunas pada umur 2, 4, 6 dan 8 MST.

Terdapat interaksi yang sangat nyata antara modifikasi media MS dan pemberian air kelapa pada umur 4, 6, dan 8 MST terhadap jumlah tunas kecuali pada umur 2 MST (Tabel 2). Data hasil uji lanjut pada peubah jumlah tunas dengan menggunakan DMRT taraf 5\% disajikan pada Tabel 4.

Tabel 4 menunjukkan bahwa jumlah tunas tertinggi terletak pada kombinasi perlakuan M3K1 (media 1/4 MS + 0 $\mathrm{ml}$ air kelapa) yaitu sebanyak 4.79 tunas pada umur 8 MST. Sedangkan jumlah tunas terendah terletak pada kombinasi perlakuan M1K3 (media MS penuh $+200 \mathrm{ml}$ air kelapa) yaitu sebanyak 0.00 tunas pada umur $8 \mathrm{MST}$. 
Tabel 3.Jumlah tunas akibat interaksi antara perlakuan modifikasi media MS dan penambahan air kelapa terhadap subkultur I tanaman anggrek Cymbidium.

\begin{tabular}{ccccc}
\hline \multirow{4}{*}{ Perlakuan Jumlah Tunas (tunas) } \\
\cline { 2 - 5 } & 2 MST & 4 MST & 6 MST & 8 MST \\
\hline M1K1 & $\begin{array}{c}1.66(1.03) \\
\mathrm{abc}\end{array}$ & $\begin{array}{r}2.08(1.08) \\
\mathrm{ab}\end{array}$ & $\begin{array}{c}3.62(1.13) \\
\mathrm{a}\end{array}$ & $\begin{array}{c}4.50(1.15) \\
\mathrm{a}\end{array}$ \\
\hline M1K2 & $\begin{array}{c}0.83(1.02) \\
\mathrm{abc}\end{array}$ & $\begin{array}{c}1.08(1.04) \\
\mathrm{d}\end{array}$ & $\begin{array}{c}1.24(1.05) \\
\mathrm{cd}\end{array}$ & $\begin{array}{c}1.60(1.06) \\
\mathrm{cd}\end{array}$ \\
\hline M1K3 & $\begin{array}{c}0.00(1.00) \\
\mathrm{d}\end{array}$ & $0.00(1.00)$ & $0.00(1.00) \mathrm{f}$ & $0.00(1.00)$ \\
$\mathrm{e}$ & & $\mathrm{e}$ \\
\hline M1K4 & $\begin{array}{c}0.33 \\
\text { (1.01) } \mathrm{cd}\end{array}$ & $\begin{array}{c}1.08(1.04) \\
\mathrm{d}\end{array}$ & $1.38(1.05)$ & $\begin{array}{c}1.68(1.06) \\
\mathrm{cd}\end{array}$ \\
\hline
\end{tabular}

\begin{tabular}{|c|c|c|c|c|}
\hline M2K1 & $\begin{array}{c}1.12(1.03) \\
\mathrm{abc}\end{array}$ & $\begin{array}{c}1.66(1.06) \\
\mathrm{bc}\end{array}$ & $\begin{array}{c}2.16(1.08) \\
b c\end{array}$ & $\begin{array}{c}3.41(1.12 \\
\mathrm{ab}\end{array}$ \\
\hline M2K2 & $\begin{array}{c}1.20 \\
(1.04) \mathrm{ab} \\
\end{array}$ & $\begin{array}{c}1.54(1.06) \\
\text { bcd }\end{array}$ & $\begin{array}{c}2.58(1.09) \\
\mathrm{b}\end{array}$ & $\begin{array}{c}3.66(1.13 \\
\mathrm{ab} \\
\end{array}$ \\
\hline M2K3 & $\mathrm{d}$ & 0.16 & $\begin{array}{c}0.50(1.02) \\
\text { ef }\end{array}$ & $\begin{array}{c}0.83(1.03) \\
\mathrm{de}\end{array}$ \\
\hline M2K4 & $\begin{array}{r}1.80(1 \\
\mathrm{a}\end{array}$ & $\begin{array}{c}2.00(1.07) \\
a b\end{array}$ & $\begin{array}{c}2.83(1.10) \\
a b\end{array}$ & $\begin{array}{c}4.54(1.15) \\
a b\end{array}$ \\
\hline M3K1 & $\begin{array}{c}1.70(1.0 \\
a b\end{array}$ & $\begin{array}{c}2.50(1 \\
\mathrm{a}\end{array}$ & $\begin{array}{c}3.75(1.13) \\
\mathrm{a}\end{array}$ & $\begin{array}{c}4.79(1.16) \\
\mathrm{a}\end{array}$ \\
\hline M3K2 & $\begin{array}{c}1.04 \\
(1.02) \mathrm{bcd}\end{array}$ & $\begin{array}{c}1.19(1.04) \\
\mathrm{cd}\end{array}$ & $\begin{array}{c}2.00(1.07) \\
\text { bcd }\end{array}$ & $\begin{array}{c}2.91(1.10) \\
\mathrm{bc}\end{array}$ \\
\hline M3K3 & $\begin{array}{c}0.66 \\
(1.00) \mathrm{d} \\
\end{array}$ & $\begin{array}{cc}1.00 & (1.04) \\
\mathrm{d}\end{array}$ & $\begin{array}{c}1.41(1.05) \\
\mathrm{cd}\end{array}$ & $\begin{array}{c}1.91(1.07) \\
\mathrm{cd}\end{array}$ \\
\hline M3K4 & $\begin{array}{c}1.00(1.02) \\
\text { bcd }\end{array}$ & $\begin{array}{c}1.00(1.04) \\
\mathrm{d}\end{array}$ & $\begin{array}{c}1.08(1.04) \\
\mathrm{de}\end{array}$ & $\begin{array}{c}1.22(1.04) \\
\mathrm{d}\end{array}$ \\
\hline \multicolumn{5}{|c|}{$\begin{array}{l}\text { Ket : Angka yang diikuti oleh huruf yang } \\
\text { sama pada kolom yang sama tidak berbeda } \\
\text { nyata berdasarkan uji DMRT pada } 0,05 \text {. Angka } \\
\text { dalam kurung adalah data hasil transformasi }= \\
\log (\mathrm{x}+10) \text {. }\end{array}$} \\
\hline
\end{tabular}

\section{Jumlah Akar.}

Hasil analisis ragam terhadap jumlah akar menunjukkan adanya pengaruh sangat nyata akibat modifikasi media MS pada umur pada umur 2 dan 8 MST, namun tidak berbeda nyata pada umur 4 dan 6 MST. Pada pemberian air kelapa menunjukkan adanya pengaruh sangat nyata terhadap jumlah akar pada umur 2 , 4, 6 dan 8 MST MST. Terdapat interaksi antara modifikasi media MS dan pemberian air kelapa pada umur tanaman 2, 4, 6 dan 8 MST terhadap jumlah akar untuk subkultur anggrek secara in vitro (Tabel 2).

Data hasil uji lanjut pada peubah jumlah akar dengan menggunakan DMRT taraf $\quad 5 \%$ disajikan pada Tabel 4. Tabel 4 menunjukkan bahwa jumlah akar tertinggi terletak pada kombinasi perlakuan M2K2 (media 1/2 MS + 100 $\mathrm{ml}$ air kelapa) yaitu sebanyak 2.55 helai pada umur 8 MST. Sedangkan jumlah akar terendah terletak pada kombinasi perlakuan M2K3 (media 1/2 $\mathrm{MS}+200 \mathrm{ml}$ air kelapa) yaitu sebanyak 0.87 helai pada umur $8 \mathrm{MST}$.

Tabel 4. Jumlah akar akibat interaksi antara perlakuan modifikasi media MS dan penambahan air kelapa terhadap sub kultur I tanaman anggrek Cymbidium.

\begin{tabular}{|c|c|c|c|c|}
\hline \multirow[b]{2}{*}{ Perlakuan } & \multicolumn{4}{|c|}{ Jumlah Akar (helai) } \\
\hline & 2 MST & $\begin{array}{c}4 \\
\text { MST }\end{array}$ & $\begin{array}{c}6 \\
\text { MST }\end{array}$ & 8 MST \\
\hline M1K1 & $\begin{array}{c}0.66(1.02) \\
\mathrm{ab}\end{array}$ & $\begin{array}{c}1.17(1.04) \\
\mathrm{a} \\
\end{array}$ & $\begin{array}{c}1.76(1.07) \\
\mathrm{ab}\end{array}$ & $\begin{array}{c}2.26 \\
(1.08) \mathrm{ab} \\
\end{array}$ \\
\hline $\mathrm{M} 1 \mathrm{~K} 2$ & $\begin{array}{c}0.16(1.01) \\
\text { bc }\end{array}$ & $\begin{array}{c}1.00(1.04) \\
\mathrm{ab}\end{array}$ & $\begin{array}{c}1.04(1.04) \\
\mathrm{de}\end{array}$ & $\begin{array}{c}1.04 \\
(1.04) \mathrm{de}\end{array}$ \\
\hline M1K3 & $\begin{array}{c}0.66(1.02) \\
\mathrm{ab}\end{array}$ & $\begin{array}{c}1.00(1.04) \\
\mathrm{ab}\end{array}$ & $\begin{array}{c}1.45(1.05) \\
\text { bc }\end{array}$ & $\begin{array}{c}1.45 \\
(1.05) \mathrm{cd} \\
\end{array}$ \\
\hline M1K4 & $\begin{array}{c}0.33(1.01) \\
\text { bc }\end{array}$ & $\begin{array}{c}1.00(1.04) \\
\mathrm{ab}\end{array}$ & $\begin{array}{c}1.18(1.04) \\
\mathrm{cd}\end{array}$ & $\begin{array}{c}1.18 \\
\text { (1.04) de }\end{array}$ \\
\hline $\mathrm{M} 2 \mathrm{~K} 1$ & $\begin{array}{c}1.00(1.04) \\
\mathrm{a}\end{array}$ & $\begin{array}{c}1.04(1.04) \\
\mathrm{ab}\end{array}$ & $\begin{array}{c}1.20(1.04) \\
\mathrm{cd}\end{array}$ & $\begin{array}{c}1.86 \\
(1.07) \mathrm{bc}\end{array}$ \\
\hline $\mathrm{M} 2 \mathrm{~K} 2$ & $\begin{array}{c}1.00(1.04) \\
\mathrm{a} \\
\end{array}$ & $\begin{array}{c}1.13(1.04) \\
\mathrm{a} \\
\end{array}$ & $\begin{array}{c}1.41(1.05) \\
\mathrm{c}\end{array}$ & $\begin{array}{c}2.55 \\
(1.09) \mathrm{a} \\
\end{array}$ \\
\hline M2K3 & $\begin{array}{c}0.00(1.00) \\
\mathrm{c}\end{array}$ & $\begin{array}{c}0.33(1.01) \\
\mathrm{c}\end{array}$ & $\begin{array}{c}0.83(1.03) \\
\mathrm{e}\end{array}$ & $\begin{array}{c}0.87 \\
(1.03) \mathrm{e} \\
\end{array}$ \\
\hline M2K4 & $\begin{array}{c}1.00(1.04) \\
\mathrm{a} \\
\end{array}$ & $\begin{array}{c}1.09(1.05) \\
\mathrm{a} \\
\end{array}$ & $\begin{array}{c}1.90(1.07) \\
\mathrm{a} \\
\end{array}$ & $\begin{array}{c}2.47 \\
(1.09) \mathrm{a} \\
\end{array}$ \\
\hline M3K1 & $\begin{array}{c}1.00(1.04) \\
\mathrm{a}\end{array}$ & $\begin{array}{c}1.05(1.04) \\
\mathrm{a} \\
\end{array}$ & $\begin{array}{c}1.47(1.05) \\
\mathrm{bc}\end{array}$ & $\begin{array}{c}2.15 \\
(1.08) \mathrm{ab}\end{array}$ \\
\hline M3K2 & $\begin{array}{c}0.66(1.02) \\
\mathrm{ab}\end{array}$ & $\begin{array}{c}1.00(1.04) \\
\mathrm{ab}\end{array}$ & $\begin{array}{c}1.34(1.05) \\
\mathrm{cd}\end{array}$ & $\begin{array}{c}1.48 \\
(1.05) \mathrm{cd} \\
\end{array}$ \\
\hline M3K3 & $\begin{array}{c}0.66(1.02) \\
\mathrm{ab}\end{array}$ & $\begin{array}{c}1.00(1.04) \\
\mathrm{ab}\end{array}$ & $\begin{array}{c}1.16(1.040) \\
\mathrm{cd}\end{array}$ & $\begin{array}{c}1.16 \\
(1.04) \mathrm{de}\end{array}$ \\
\hline M3K4 & $\begin{array}{c}0.66(1.02) \\
\mathrm{ab}\end{array}$ & $\begin{array}{c}0.83(1.04) \\
a b\end{array}$ & $\begin{array}{c}1.05(1.04) \\
\mathrm{de}\end{array}$ & $\begin{array}{c}1.25 \\
(1.05) \mathrm{de}\end{array}$ \\
\hline $\begin{array}{l}\text { Ket : Angk } \\
\text { yang sama } \\
0,05 \text {. Angk } \\
\log (x+10) \text {. }\end{array}$ & $\begin{array}{l}\text { ang diikuti } \\
\text { ak berbeda } \\
\text { lalam kurun }\end{array}$ & $\begin{array}{l}\text { leh huruf } \\
\text { yata berda } \\
\text { adalah do }\end{array}$ & ang sama 1 & $\begin{array}{l}\text { da kolom } \\
\text { ART pada } \\
\text { formasi = }\end{array}$ \\
\hline
\end{tabular}




\section{Tinggi Tunas.}

Hasil analisis ragam terhadap jumlah menunjukkan adanya pengaruh sangat nyata akibat modifikasi media MS pada umur 2, 4, 6 dan 8 MST. Pada pemberian air kelapa menunjukkan adanya pengaruh sangat nyata terhadap tinggi tunas pada umur 2, 4, 6 dan 8 MST. Terdapat interaksi antara modifikasi media MS dan pemberian air kelapa pada umur 2-8 MST

terhadap tinggi tunas subkultur anggrek secara in vitro (Tabel 2). Data hasil uji lanjut pada peubah tinggi tunas dengan menggunakan DMRT taraf $5 \%$ disajikan pada Tabel 5 .

Tabel 5 menunjukkan bahwa tinggi tunas tertinggi terletak pada kombinasi perlakuan M2K4 (media $1 / 2$ $\mathrm{MS}+300 \mathrm{ml}$ air kelapa) yaitu sebesar $2.10 \mathrm{~cm}$ pada umur 8 MST. Sedangkan tinggi tunas terendah terletak pada kombinasi perlakuan M1K3 (media MS penuh $+200 \mathrm{ml}$ air kelapa) yaitu sebesar $0.00 \mathrm{~cm}$ umur $8 \mathrm{MST}$.

Tabel 5. Tinggi tunas akibat interaksi antara perlakuan modifikasi media MS dan penambahan air kelapa terhadap sub kultur I tanaman anggrek Cymbidium.

\begin{tabular}{ll}
\hline Perlakuan & Tinggi Tunas (Cm) \\
\hline M1K1 & $1.75(1.06) \mathrm{ab}$ \\
\hline M1K2 & $0.76(1.03) \mathrm{defg}$ \\
\hline M1K3 & $0.00(1.00) \mathrm{h}$ \\
\hline M1K4 & $0.37(1.01) \mathrm{fgh}$ \\
\hline M2K1 & $1.23(1.05) \mathrm{bcd}$ \\
\hline M2K2 & $1.00(1.04) \mathrm{cde}$ \\
\hline M2K3 & $0.50(1.02) \mathrm{efgh}$ \\
\hline M2K4 & $2.10(1.08) \mathrm{a}$ \\
\hline M3K1 & $1.51(1.06) \mathrm{abc}$ \\
\hline M3K2 & $0.97(1.03) \mathrm{cdef}$ \\
\hline M3K3 & $0.36(1.01) \mathrm{gh}$ \\
\hline M3K4 & $0.56(1.02) \mathrm{efgh}$ \\
\hline
\end{tabular}

Ket : Angka yang diikuti oleh huruf yang sama pada kolom yang sama tidak berbeda nyata berdasarkan uji DMRT pada 0,05. Angka dalam kurung adalah data hasil transformasi $=$ $\log (\mathrm{x}+10)$.

\section{Pembahasan.}

Hasil pengamatan menunjukkan bahwa interaksi perlakuan modifikasi media MS dan pemberian air kelapa memberikan pengaruh nyata terhadap peubah persentase tumbuh tunas, jumlah tunas, jumlah akar dan tinggi tunas tanaman subkultur anggrek secara in vitro dari umur tanaman 2-8 MST.

Namun perlakuan modifikasi media MS dan pemberian air kelapa tidak memberikan pengaruh nyata terhadap peubah jumlah tunas tanaman anggrek secara in vitro pada umur 2 MST.

Perlakuan modifikasi media MS dengan penambahan air kelapa berpengaruh nyata terhadap persentase tumbuh tunas tanaman subkultur anggrek cymbidium secara in vitro pada masingmasing faktor kombinasi pada umur tanaman 2-8 MST. Secara rataan persentase tumbuh tunas tertinggi terdapat pada perlakuan M2K2 (media 1/2 $\mathrm{MS}+$ air kelapa $100 \mathrm{ml}$ ), sedangkan yang terendah terdapat pada perlakuan M1K3 (media MS penuh + air kelapa $200 \mathrm{ml}$ ).

Semua perlakuan telah mampu mempengaruhi persentase tumbuh tunas pada eksplan subkultur anggrek Cymbidium, meskipun memiliki persentase tumbuh tunas yang berbedabeda. Perlakuan M2K1 menunjukkan persentase tumbuh tunas paling tinggi. Perlakuan ini membuktikan bahwa dalam menumbuhkan tunas tidak memerlukan konsentrasi media MS yang penuh serta konsentrasi air kelapa yang tinggi pada eksplan subkultur anggrek Cymbidium. Hal ini diduga karena media $1 / 2$ MS masih sangat baik dalam menumbuhkan tunas subkultur tanaman anggrek 
Cymbidium meski dalam komposisi yang dikurangi. Selain itu penambahan air kelapa dengan konsentrasi yang rendah lebih efektif dalam persentase tumbuh tunas tanaman subkultur anggrek Cymbidium karena penambahan air kelapa pada konsentrasi ini menyebabkan pembelahan dan pembentangan sel berlangsung lebih optimal.

Hal ini sesuai dengan penelitian Annatje et al., (2016) bahwa perlakuan media $1 / 2$ MS menyebabkan rata-rata persentase eksplan bertunas yang tertinggi dan berbeda dengan perlakuan lain. Matatula (2003) menambahkan bahwa penambahan air kelapa dalam media tanam dengan kadar yang rendah justru akan membantu proses pertumbuhan vegetatif tanaman karena kandungan $\mathrm{N}$ serta hormon lain yang dibutuhkan oleh tanaman anggrek cukup.

Air kelapa memiliki kandungan yang beragam di dalamnya. Berdasarkan hasil analisis menggunakan teknik High Performance Liquid Chromatografi (HPLC) air kelapa muda mengandung ZPT golongan sitokinin seperti kinetin $273,62 \mathrm{mg} / \mathrm{l}$ dan zeatin $290,47 \mathrm{mg} / 1$ serta ZPT auksin 198,55 mg/l. Air kelapa juga mengandung vitamin yang dapat dijadikan subtitusi vitamin sintetik dalam media MS seperti vitamin C $8,9 \mathrm{mg} / 1$, vitamin B5 0,60 mg/l, inositol 2,30 mg/l, thiamin $0,02 \mathrm{mg} / \mathrm{l}$ dan pridoksin 0,03 $\mathrm{mg} / \mathrm{l}$. Selain kandungan ZPT dan vitamin air kelapa juga mengandung unsur haro makro dan mikro seperti $\mathrm{N} 43,00$ $\mathrm{mg} / \mathrm{l}, \mathrm{P} 13,17 \mathrm{mg} / \mathrm{l}, \mathrm{K} 14,11 \mathrm{mg} / \mathrm{l}, \mathrm{Mg}$ 9,11 mg/l, Fe 0,2 mg/l, Ca 24,67 mg/1 dan $\mathrm{Zn} 1,05 \mathrm{mg} / \mathrm{l}$. Selain itu, air kelapa mengandung sukrosa $4,89 \mathrm{mg} / 1$ sebagai sumber karbon pertumbuhan tanaman in vitro (Kristina dan Syahid, 2012).

Air kelapa yang ditambakan pada media MS akan meningkatkan pembentukan tunas tanaman krisan dan anggrek (Matatula, 2003). Air kelapa mengandung zat-zat aktif untuk perkembangan embrio seperti sitokinin yang berperan dalam memacu pembelahan sel (Surachman, 2011). Pemberian hormon atau zat pengatur tumbuh (ZPT) sitokinin berpengaruh terhadap pertumbuhan tunas dan dapat menyebabkan tunas tumbuh lebih cepat. Hormon sitokinin berperan penting dalam merangsang proses pembelahan sel tumbuhan sehingga mempercepat pertumbuhan tunas (Anisa, 2018). Unsur hara nitrogen beserta unsur hara lainnya dalam air kelapa berperan penting untuk perturnbuhan eksplan dan diferensiasi jaringan protokorm membentuk tunas (Setiawati, 2010).

Perlakuan modifikasi media MS dengan penambahan air kelapa berpengaruh nyata terhadap jumlah tunas tanaman subkultur anggrek cymbidium secara in vitro pada masing-masing faktor kombinasi pada umur tanaman 4, 6, dan 8 MST. Secara rataan jumlah tunas tertinggi terdapat pada perlakuan M3K1 (media $1 / 4 \quad \mathrm{MS}+$ air kelapa $0 \mathrm{ml}$ ), sedangkan yang terendah terdapat pada perlakuan M1K3 (media MS penuh + air kelapa $200 \mathrm{ml}$ ).

Semua perlakuan berpengaruh pada jumlah tunas eksplan subkultur anggrek Cymbidium, meskipun memiliki jumlah tunas yang berbeda-beda. Perlakuan M3K1 menunjukkan jumlah tunas paling tinggi. Perlakuan ini membuktikan bahwa media 1/4 MS tanpa pemberian air kelapa masih sangat baik dalam menumbuhkan tunas tanaman subkultur anggrek Cymbidium meski dalam komposisi yang dikurangi dan tanpa adanya penambahan hormon eksogen. Hal ini diduga karena pada media MS terkandung unsur- unsur hara, baik makro maupun mikro yang 
merupakan unsur penting dalam pertumbuhan tanaman secara in vitro, meskipun dikurangi kandungan tersebut masih berpengaruh terhadap jumlah tunas tanaman subkultur anggrek Cymbidium, sehingga perlakuan yang tidak ditambahi hormon eksogen dari air kelapa masih menumbuhkan tunas karena dibantu oleh hormon endogen pada eksplan.

Hal ini sesuai dengan penelitian Purwanto et al., (2007) bahwa modifikasi media MS sampai 1/4 MS masih cukup baik untuk pertumbuhan eksplan tanaman kentang. Pertumbuhan dan morfogenesis tanaman secara in vitro dikendalikan oleh keseimbangan dan interaksi dari zat pengatur tumbuh (ZPT) yang berada dalam eksplan dan akan menentukan arah dari pengembangan kultur seperti pertumbuhan tunas. ZPT pada eksplan tergantung dari ZPT endogen di dalamnya dan eksogen, yang diserap dari media tumbuh dalam menumbuhkan tunas pada eksplan (Tuhuteru et al., 2012).

Gunawan (2007) menambahkan pertumbuhan dan morfogenesis tanaman secara in vitro dikendalikan oleh keseimbangan dan interaksi antara zat pengatur tumbuh baik yang terkandung dalam eksplan itu sendiri (endogen) maupun yang diserap dari media (eksogen). Pembentukan tunas tidak terlepas dari pengaruh dari zat pengatur tumbuh sitokinin yang terdapat dalam air kelapa antara lain 9,8-D ribofuronasil zeatin, zeatin, N-N-Diphenyl urea, 2 (3methyl butan-2 enylamino)-purin (Gamborg dan Phllips, 1995). Selain itu adanya unsur hara makro dan mikro di dalam air kelapa seperti unsur hara nitrogen beserta unsur hara lainnya berperan penting untuk perturnbuhan eksplan dan diferensiasi jaringan protokorm membentuk tunas.

Perlakuan modifikasi media MS dengan penambahan air kelapa berpengaruh nyata terhadap jumlah akar tanaman subkultur anggrek cymbidium secara in vitro pada masing-masing faktor kombinasi pada umur tanaman 28 MST. Secara rataan jumlah akar tertinggi terdapat pada perlakuan M2K2 (media $1 / 2 \mathrm{MS}+$ air kelapa $100 \mathrm{ml}$ ), sedangkan yang terendah terdapat pada perlakuan M2K3 (media 1/2 MS + air kelapa $200 \mathrm{ml}$ ).

Semua perlakuan telah mampu menumbuhkan akar pada eksplan subkultur anggrek Cymbidium, meskipun memiliki jumlah akar yang berbedabeda. Perlakuan M2K2 menunjukkan jumlah akar paling tinggi. Perlakuan ini membuktikan bahwa dalam pertumbuhan tunas tidak memerlukan konsentrasi media MS yang penuh serta konsentrasi air kelapa yang tinggi pada eksplan subkultur anggrek Cymbidium. Hal ini diduga karena media $1 / 2$ MS masih sangat baik dalam menumbuhkan akar subkultur tanaman anggrek Cymbidium meski dalam komposisi yang dikurangi. Selain itu penambahan air kelapa dengan konsentrasi yang rendah lebih berpengaruh pada jumlah akar tanaman subkultur anggrek Cymbidium akibat adanya pengaruh dari hormon eksogen dari air kelapa dengan konsentrasi yang tepat.

Hal ini sesuai dengan penelitian Purwanto et al., (2007) bahwa modifikasi media $1 / 2$ MS dan penambahan air kelapa merupakan media yang baik untuk induksi akar. Tuhuteru et al., (2012) menambahkan bahwa pengaruh

perlakuan pemberian konsentrasi air kelapa terhadap jumlah total akar plantlet anggrek D. anosmum, yakni media perlakuan dengan konsentrasi 50 dan $100 \mathrm{ml} / \mathrm{l}$ menghasilkan jumlah akar terbanyak.

Air kelapa mengandung sitokinin, zeatin dan auksin serta vitamin dan mineral yang dapat meningkatkan multiplikasi tanaman in vitro. Auksin yang terkandung di dalam air kelapa 
dapat merangsang pertumbuhan akar tanaman anggrek apabila sesuai dengan konsentrasi optimumnya. Hal ini sesuai dengan penelitian Armini et al., (1991) bahwa perbandingan auksi dan sitokinin yang digunakan mempengaruhi pembentukan tunas dan akar dalam kultur jaringan. Perbandingan antara sitokinin dan auksin yang tinggi akan mendorong pembentuka tunas, sedangkan perbandingan sitokinin dan auksin rendah akan mendorong pembentukan akar, sebab air kelapa adalah endosperm yang kaya akan makanan, maka jika air kelapa tersebut ditambahkan dalam media kultur jaringan, eksplan yang ditanam dapat tumbuh dengan baik. Menurut Hendaryono dan Wijayani (1994) keseimbangan antara sitokinin dan auksin akan menghasilkan tunas dan akar. Hal ini terlihat pada hasil kultur dalam setiap eksplan mampu membentuk tunas dan akar hampir pada semua perlakuan.

Auksin sangat berpengaruh dalam induksi akar. Auksin dan sitokinin yang rendah,cenderung akan mendorong pertumbuhan tunas dan daun. Sebaliknya, apabila auksin dan sitokinin tinggi, maka akan menumbuhkan akar, sedangkan auksin dan sitokinin yang seimbang akan mendukung bagi pertumbuhan tunas, daun dan akar yang berimbang pula. Konsentrasi zat pengatur tumbuh auksin atau sitokinin untuk pertumbuhan tunas pada setiap tanaman tidak selalu sama. Jenis dan konsentrasi zat pengatur tumbuh untuk memacu pertumbuhan tunas tergantung beberapa faktor, antara lain jenis tanaman, jaringan atau organ yang digunakan, keadaan fisiologi eksplan, serta kandungan sitokinin dan auksin endogen di dalam jaringan (Lestari, 2011).

Menurut Mustakim et al., (2015) pertumbuhan akar juga tergantung pada peran unsur fosfor, kalsium, mangan, besi, dan boron. Selain itu thiamin yang terkandung dalam media MS berfungsi untuk mempercepat pembelahan sel pada meristem akar, serta berperan dalam koenzim dalam reaksi yang menghasilkan energi dan karbohidrat. Di dalam air kelapa terdapat unsur thiamin yang merupakan golongan vitamin B1 yang berfungsi mempercepat pembelahan sel pada meristem akar. Selain itu unsur kalsium yang terdapat dalam air kelapa juga berperan dalam pembentukan bulubulu akar dan pemanjangan akar.

Perlakuan modifikasi media MS dengan penambahan air kelapa berpengaruh nyata terhadap tinggi tunas tanaman subkultur anggrek Cymbidium secara in vitro pada masing-masing faktor kombinasi pada umur tanaman 8 MST. Tinggi tunas yang baik pada akhir pengamatan (8 MST). Secara rataan tinggi tunas tertinggi terdapat pada perlakuan M2K4 (media 1/2 MS + air kelapa $300 \mathrm{ml}$ ), sedangkan yang terendah terdapat pada perlakuan M1K3 (media MS penuh + air kelapa $200 \mathrm{ml}$ ).

Semua perlakuan telah berpengaruh terhadap tinggi tunas pada eksplan subkultur anggrek Cymbidium, meskipun memiliki tinggi tunas yang berbeda-beda. Perlakuan M2K4 menunjukkan tinggi tunas paling tinggi. Perlakuan ini membuktikan bahwa dalam menumbuhkan akar tidak memerlukan konsentrasi media MS yang penuh namun memerlukan konsentrasi airkelapa yang tinggi pada eksplan subkultur anggrek Cymbidium. Hal ini diduga karena media $1 / 2$ MS masih sangat baik dalam pertambahan tingggi tunas subkultur tanaman anggrek Cymbidium meski dalam komposisi yang dikurangi. Selain itu penambahan air kelapa dengan konsentrasi yang tinggi lebih efektif berpengaruh pada tinggi tunas tanaman subkultur anggrek Cymbidium akibat adanya pengaruh dari hormon eksogen dari air kelapa.

Menurut Pranata et al., (2015) dalam penelitiannya, penambahan air 
kelapa 22,5\% memberikan pertumbuhan tinggi tanaman paling baik, kemudian diikuti dengan penambahan air kelapa $15 \%$. Hal ini membuktikan bahwa pemberian air kelapa dengan konsentrasi lebih tinggi akan berpengaruh pada tinggi tunas tanaman secara in vitro.

Hal ini sesuai dengan penelitian Armini et al., (1991) bahwa selain meningkatkan jumlah tunas terbanyak penambahan air kelapa juga dapat meningkatkan aktifitas sitokinin endogen yang selanjutnya meningkatkan efektifitas pembelahan sel semakin tinggi. Di dalam air kelapa terdapat zat hara, hormon, dan vitamin yang dapat merangsang pertumbuhan plantlet. Selain itu, senyawa nitrogen $(\mathrm{N})$ yang terkandung dalam media berperan dalam sintesis asam-asam amino dan protein secara optimal yang selanjutnya digunakan dalam proses pertumbuhan dan perkembangan tanaman (Tuhuteru et al., 2012).

Adanya unsur hara makro dalam air kelapa seperti kalium juga membantu dalam pemanjangan sel tanaman anggrek secara in vitro. Selain itu vitamin C yang terdapat di dalam air kelapa dapat membantu merangsang pertumbuhan batang tanaman. Pemanjangan batang terjadi karena adanya proses pembelahan sel, pemanjangan sel dan pembesaran sel-sel baru yang terjadi pada maristem ujung batang yang mengakibatkan tanaman bertambah tinggi (Widiastoety, 2003).

Perlakuan modifikasi media MS dengan penambahan air kelapa tidak berpengaruh nyata terhadap jumlah tunas tanaman subkultur anggrek cymbidium secara in vitro pada umur tanaman 2 MST namun berpengaruh nyata pada umur tanaman $4-8$ MST. Hal ini diduga karena pada umur tanaman 2 MST tanaman subkultur anggrek lambat dalam penyerapan unsur-unsur yang terkandung di dalam media seperti sitokinin yang berfungsi untuk pembelahan sel dalam menumbuhkan tunas, sehingga pada umur tanaman 2 MST pertumbuhan tunas juga sedikit dan hanya pada faktor kombinasi tertentu. Selain itu konsentrasi air kelapa yang berbeda juga akan mempengaruhi kandungan ZPT yang ada di dalamnya. Sehingga juga mempengaruhicepat atau lambatnya sel membelah. Hal ini sesuai dengan peneletian Hendaryono dan Wijayani (1994) bahwa kombinasi sitokinin aktif berperan dalam penggandaan tunas dan tinggi tunas sampai jangka waktu akhir pengamatan, meskipun jumlah dan tinggi tunas yang terbentuk pada awal pengamatan masih rendah.

Davies (1995) menyatakan bahwa pemberian sitokinin pada media kultur menyebabkan pembelahan sel pada permulaan kultur berjalan lambat, akan tetapi populasisel tetap dijaga dan kemudian jumlahnya ditingkatkan. Perbedaan jumlah tunas yang terbentuk pada tiap perlakuan dipengaruhi oleh sitokinin pada konsentrasi yang berbeda. Hal ini sesuai dengan pendapat Wattimena et al., (1988) bahwa kecepatan sel membelah diri dapat dipengaruhi oleh adanya kombinasi ZPT tertentu dalam konsentrasi yang tertentu.

Menurut Santoso dan Nursandi (2004) variasi data bisa terjadi dikarenakan masing- masing eksplan memiliki kepekaan sel yang berbeda-beda terhadap rangsang yang diberikan, seperti raksang hormon eksogen yang diberikan. Lebih lanjut Indriani (2014) menyatakan bahwa penambahan konsentrasi air kelapa yang berbeda menunjukkan respon tumbuh yang berbeda pula.

\section{Kesimpulan}

Kesimpulan yang diperoleh dari penelitian ini yaitu :

1. Perlakuan modifikasi media MS berpengaruh nyata terhadap pertumbuhan tanaman anggrek Cymbidium secara in vitro. Hal ini 
dapat dilihat pada peubah persentase tumbuh tunas pada umur tanaman 2, 4, 6 dan 8 MST, jumlah tunas 2, 4, 6 dan 8 MST, jumlah akar 2 dan 8 MST dan tinggi tunas pada umur tanaman 2, 4, 6 dan 8 MST.

2. Perlakuan penambahan air kelapa pada media MS berpengaruh nyata terhadap pertumbuhan tanaman anggrek Cymbidium secara in vitro. Hal ini dapat dilihat pada peubah persentase tumbuh tunas, jumlah tunas, jumlah akar, dan tinggi tunas pada umur tanaman 2, 4, 6 dan 8 MST.

3. Terdapat interaksi antara kombinasi perlakuan modifikasi media MS dan penambahan air kelapa disemua peubah pada umur tanaman 2, 4, 6 dan 8 MST kecuali pada peubah jumlah tunas pada umur tanaman 2 MST.

\section{Daftar Pustaka}

Annatje E.B., Jeany M, dan Semuel R. 2016. Substitusi Media Murashige dan Skoog/MS dengan Air Kelapa dan Pupuk Daun Majemuk pada Pertumbuhan Anggrek Dendrobium secara in vitro. Jurnal Bioslogos. Vol: 6(1).

Anisa, T. 2018. Pengaruh lama perendaman biji dan konsentrasi $B A P$ terhadap perkecambahan biji jeruk manis Berastagi local (Citrus nobilis) Brastepu secara in vitro. Fakultas Pertanian Universitas Malikussaleh: Aceh Utara.

Anonymous. 2011. Buku Seri Konservasi-1 "Keanekaragaman Hayati Jenis Anggrek Taman Nasional Bukit Baka Bukit Raya". Diakses dari http://bukitbakabukitraya.org/w-
content/uploads/2012/09/Bukuseri-informasi-konservasi-1.pdf [diakses tanggal 22 Januari 2018].

Arditti, J. 1992. Fundamentals of Orchids Biology. John Wiley and

Sons, Inc: New York.

Armini, G.A. Wattiimena, dan L.W. Gunawan. 1991. Perbanyakan tanaman: Bogor. $307 \mathrm{hlm}$.

Bey, Y, Syafii, W. dan Sutrisna. 2006. Pengaruh Pemberian Giberelin (GA3) dan Air Kelapa Terhadap Perkecambahan Biji Anggrek Bulan (Phalaenopsis ambilis BL) Secara In Vitro. Jurnal Biogenesis. Vol: 2(2):4146.

Budiarta, A. 2004. Dasar- dasar Kultur Jaringan. Pusat Pengembangan dan Penataran Guru Pertanian: Cianjur.

Bhojwani, S.S. dan M.K. Razdan. 1996. Plant Tissue Culture: Theory and

Practice. Elsevier: Amsterdam.

Comber, J.B. 1990. Orchids of Java. Bentham-Moxon Trust. The Royal Botanic Gardens, Kew.

Davies, J.P. $1995 . \quad$ Plant hormone: their nature, occurrence and function. KluwerAcademic Publisher: Boston.

Hendaryono, D.P.S. dan A. Wijayani. 1994. Kultur Jaringan (Pengenalan dan Petunjuk Perbanyakan Tanaman Secara Vegetatif Media). Kanisius: Yogyakarta.

Gamborg, O. L., G. C. Phillips. 1995. Media Preparation and Handling. p 21-33. Springer-Verlag. Berlin

Gunawan H. 2007. Mikropropagasi Tunas Stroberi dengan Pemberian NAA dan BAP pada Media MS.

Skripsi. Program Studi Pemuliaan Tanaman. Departemen Budidaya Pertanian. 
Fakultas Pertanian. Universitas Sumatera Utara. Medan. $95 \mathrm{hlm}$. Indriani, B.S. 2014. Efektivitas Substitusi Sitokinin dengan Air Kelapa pada Medium Multiplikasi Krisan (Chrysanthemum indicum L.) secara In Vitro. Skripsi, Jurusan Biologi FMIPA Universitas Negeri Semarang.

Iswanto, H. 2002. Petunjuk Perawatan Anggrek. Agromedia Pustaka: Jakarta. Kasutjianingati dan Irawan, R. 2013. Media alternative perbanyakan in vitro anggrek bulan (Phalaenopsis amabilis). Jurnal. Vol: 3( 3):184189. Karjadi dan Buchory. 2008. Pengaruh

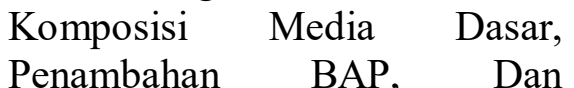
Pikloram Terhadap Induksi Tunas Bawang Merah. J. Hort. 18(1):1-9

Kristina N.N. \& Syahid F.A. 2012. Pengaruh Air Kelapa Terhadap Multiplikasi Tunas In

Vitro, Produksi Rimpang, Dan Kandungan Xanthorrhizol Temulawak Di Lapangan. Jurnal

Littri. Vol: 18(3):125-126.

Lestari, E G. 2011. Peranan Zat Pengatur Tumbuh dalam Perbanyakan Tanaman melalui Kultur Jaringan. Jurnal AgroBiogen. Vol:7 (1).

Mardin, S., 2002. Media Tumbuh Kultur Jaringan Tanaman. Makalah pada Pelatihan Kultur Jaringan Tanaman PS Agronomi Unsoed: Purwokerto.

Marlina, N. 2004. Teknik modifikasi media Murashige dan Skoog (MS) untuk konservasi in vitro mawar (Rossa sp.). Buletin Teknik Pertanian. Vol: 9(1):4-7.

Matatula, A. J. 2003. Substitusi media MS dengan air kelapa dan Gandasil-D pada kultur jaringan krisan. Vol: 9(4): 203-211.

J. Eugenia. Mustakim, B. F. Wahidah1, A. AlFauzy. 2015. Pengaruh penambahan air kelapa terhadap pertumbuhan stek

mikro tanaman krisan

(Chrysanthemum indicum) secara in vitro. Jurusan Biologi, Fakultas Sains dan Teknologi, UIN Alauddin: Makassar.

Netty, W. 2002. Optimasi Medium untuk Multiplikasi Tunas

Kana (Canna hibryda Hort.) dengan Penambahan Sitokinin. J. Biosains dan Bioteknologi Indonesia. Vol: 2 (1):27-31.

Pranata, M.G, Yunus ,A. dan Pujiasmanto, B. 2015. Pengaruh konsentrasi naa dan air kelapa terhadap multiplikasi temulawak (curcuma xanthorrizha roxb.) secara in vitro. UNS: Journal of Sustainable Agriculture. Vol: 30(2)

Purwanto, A.S.D. Purwantono, dan S. Mardin. 2007. Modifikasi Media Ms dan Perlakuan Penambahan Air Kelapa Untuk Menumbuhkan Eksplan Tanaman Kentang. Purwokerto: Jurnal Penelitian dan Informasi Pertanian “Agrin”. Vol: 11(1).

Purwantoro, A., Ambarwati, dan Setyaningsih. 2005.

Kekerabatan Antar Anggrek Spesies Berdasarkan Sifat Morfologi Tanaman Dan Bunga. Ilmu Pertanian Vol: 12(1).Rahardja, P. C., dan Wahyu, W. 2003. Aneka Cara Memperbanyak Tanaman. Agromedia Pustaka: Jakarta. Raynalta E., dan sukma D. 2013. Pengaruh komposisi media dalam perbanyakan protocorm like bodies, pertumbuhan planlet, dan aklimatisasi Phalaenopsis amabilis. Jurnal hortikultura 
Indonesia. Vol: 4(3):131-139

Rohayati, E. dan N. Marlina. 2009. Teknik Aklimatisasi Planlet Anyelir (Dianthus caryophyllus L.) untuk Tanaman Induk. Buletin Teknik Pertanian. Vol: 14(2): 72-75.

Santoso, U. dan Nursandi, F. 2004. Kultur Jaringan Tanaman. Universitas Muhammadiyah Malang: Malang.

Seswita, D. 2010. Penggunaan Air Kelapa Sebagai Zat Pengatur Tumbuh Pada Multiplikasi Tunas Temulawak (Curcuma xanthhorrhiza roxb.) in vitro. Jurnal Littri. Vol: 16(4):135-140.

Setiawati, T., S. Sanoesi., S. Muliati. 2010. Pupuk Daun dan Air Kelapa Sebagai Medium Alternatif untuk Induksi Tunas Anggrek Dendrobium Whom Leng in vitro. Jurnal Biotika. Vol: 8(1):4-54

Soedarjo M, H. Shintiavira, Y. Supriyadi \& Y. Nasihin. 2012. Peluang Bisnis Inovasi Krisan Badan LitbangPertanian. Agro inovasi: Jakarta Selatan.

Sudarmadji. 2003. Penggunaan Benzil Amino Purine pada Pertumbuhan Kalus Kapas Secara In Vitro. Buletin Teknik Pertanian. Vol: 8(1):28-30.

Sukma, D dan A. Setiawati. 2010. Pengaruh waktu dan frekuensi aplikasi pupuk daun terhadap pertumbuhan dan pembungaan anggrek Dendrobium 'Tong Chai Gold'. J. Hort. Indonesia. Vol: 1(2): 97-104.

Surachman D. 2011. Teknik pemanfaatan air kelapa untuk perbanyakan nilam secara in vitro. Buletin Teknik Pertanian. Vol: 16(1):31-33.
Sutiyoso, Y. 2004. Hidroponik ala Yos. Penebar Swadaya: Jakarta.

Tuhuteru S., M. L. Hehanussa,S.H.T. Raharjo.2012.Pertumbuhan dan perkembangan anggrek Dendrobium anosmum pada media kultur in vitro dengan beberapa konsentrasi air kelapa. Agrologia. Vol: 1 (1):112

Upreti, K.K. \& Sharma, M. (2016) Role of Plant Growth Regulators in Abiotic Stress Tolerance.

AbioticStress Physiology of Horticultural Crops: India, pp.19-46. doi:10.1007/978-81322-2725-0.

Vigliar, R., V.L. Sdepanian, and U. fagundes- neto. 2006. Biochemical profile of coconut water from coconut palms planted in an inland region. $J$. de Pediatria. Vol: 82(4): 308-312.

Wattimena, G.A. 1988. Zat Pengatur Tumbuh Tanaman. Laboratorium Kultur Jaringan. Tanaman PAU Bioteknologi IPB. Bogor. 145 hlm.

Wetherell, D.F. 1982. Pengantar Propagasi Tanaman Secara In Vitro. Semarang: IKIP Semarang Press.

Widiastoety, d. dan Purbadi. 2003. Pengaruh Bubur Ubi

Kayu dan Ubi Jalar terhadap Pertumbuhan Plantlet Anggrek

Dendrobium. Jurnal Hortikultural. Vol: 13(1):1-6.

Widiastoety, D., N. Solvia, M. Soedarjo. 2010. Potensi anggrek Dendrobium dalam meningkatkan variasi dan kualitas anggrek bunga potong. Jurnal Litbang Pertanian. 29:101-106

Widyastuti, N. Dan D. Tjokrokusumo. 2001.Peranan beberapa zat pengatur tumbuh (ZPT) tanaman 
pada kultur in vitro. Jurnal

Sains dan Teknologi Indonesia.

Vol: (5):55-63.

Yunita, R. 2011. Pengaruh Pemberian

Urine Sapi, Air Kelapa, dan

Rootone- F Terhadap

Pertumbuhan Setek Tanaman

Markisa (Passiflora edulis var.

flavicarpa). Fakultas Pertanian

Universitas Andalas: Padang.

Yusnita. 2003. Kultur jaringan:

Cara Memperbanyak Tanaman

Secara Efisien. Agro Media

Pustaka: Jakarta.

$105 \mathrm{hlm}$.

Yusnita. 2010. Perbanyakan In

Vitro Tanaman Anggrek.

Universitas Lampung. Lampung.

$128 \mathrm{hlm}$.

Zulkarnain, 2011. Kultur Jaringan

Tanaman. Jakarta: Bumi Aksara 